\title{
Andrzej Luczyszyn
}

WSB University in Wrocław

e-mail: aluczyszyn@wp.pl

ORCID: 0000-0003-4212-7686

\section{TERRITORY, GLOCALISATION AND TERRITORIALISATION AS DEVELOPMENT DETERMINANTS \\ TERYTORIUM, GLOKALIZACJA I TERYTORIALIZACJA JAKO DETERMINANTY ROZWOJU}

DOI: $10.15611 / \mathrm{br} .2021 .1 .07$

JEL Classification: R10, R11, R58

\section{(C) 2021 Andrzej Łuczyszyn}

This work is licensed under the Creative Commons Attribution-ShareAlike 4.0 International License. To view a copy of this license, visit http://creativecommons.org/licenses/by-sa/4.0/

Quote as: Łuczyszyn, A. (2021). Territory, glocalisation and territorialisation as development determinants. Biblioteka Regionalisty. Regional Journal, (21).

\begin{abstract}
At a time when the world economy is experiencing rapid changes, a new paradigm of development referred to as a territory-oriented approach is growing in importance. This shift in the general concept of development is driven by a multitude of factors, including in particular the fact that development is a historical product and as such it has its own temporal dimension. Both regional and local developments are dynamic models where constant interactions occur between local and global elements. These interactions create a system in which spatially concentrated and historically formed technical, productive and institutional activities are performed and coordinated in a variety of ways by all kinds of organizations, in other words a territory. One may argue that territories evolve and their history is made up of subsequent development stages and of new external situations which compel them to make continuous adjustments. Within their borders, there is an ongoing combination of development factors, with the territory's differentiating features being unique and not easily replicable. As such, territories are specific social structures. Contemporary social realities require that local and regional dimensions be brought up together with the world - a global dimension. This makes territories a stage for economic actors.
\end{abstract}

Keywords: territory, glocalisation, territorialisation. 
Streszczenie: W dobie dynamicznych zmian w światowej gospodarce rośnie znaczenie nowego paradygmatu rozwoju zwanego rozwojem ukierunkowanym terytorialnie. Ta zmiana ogólnej koncepcji rozwoju determinowana jest wieloma czynnikami, a przede wszystkim tym, że jest ona wytworem historycznym, a więc ma wymiar czasowy. Zarówno rozwój regionalny, jak i lokalny są modelami dynamicznymi, w których istnieją ciągłe interakcje między elementami lokalnymi i globalnymi. Interakcje te tworzą system przestrzennie skoncentrowanych i historycznie ukształtowanych działalności technicznych, produkcyjnych i instytucjonalnych, wykonywanych i skoordynowanych w różny sposób przez wszelkiego rodzaju organizacje, czyli terytorium. Można stwierdzić, że terytoria kształtują się w sposób ewolucyjny, a ich historię tworzą kolejne, następujące po sobie fazy rozwoju oraz nowe sytuacje zewnętrzne, zmuszające je do ciągłego dostosowywania się. W ich granicach występuje nieustająca kombinacja czynników rozwoju, a cechy je odróżniające są niepowtarzalne i z trudem można je odtwarzać na innych obszarach. Terytoria zatem są specyficznymi konstrukcjami społecznymi. Współczesne realia społeczne wymagają łączenia wymiaru lokalnego i regionalnego z wymiarem światowym - globalnym. To sprawia, że terytoria są areną gry aktorów ekonomicznych.

Słowa kluczowe: terytorium, glokalizacja, terytorializacja.

\section{Introduction}

In today's socio-economic realities, trying to counter the global and local dimensions of economic activity no longer seems to be a viable approach and in fact is not borne out by reality. What we are seeing is a variety of economic actors capable of integrating powers and moving local and regional economies away from the traditional direction. Lately, the term 'territory' has acquired greater economic and social relevance, which although commonly associated with a region, regional or local development, differs from these categories owing to the shift within the paradigm of regional development towards making it territorial. One could argue that what is becoming more apparent is the need for creating, reinforcing and using local and regional ties with a view to strengthening the policy of territorial development. In other words, the territorial approach towards development is steadily gaining in importance. In terms of economic practice this is demonstrated, for instance, in that a territory enables businesses to take root, while society can pursue creative activities. With this kind of socio-economic progress, space has become a relational space, that is, a space capable of spreading innovation. This leads to establishing new relations between businesses, administration, scientific institutions and social organizations, which, in turn, means that added value and new resources are being created. These circumstances allow location to gain special importance, given its critical role in building competitive advantage, while also creating an opportunity for local and global platforms to intersect, thus inducing the new paradigm of territorial development. The territorialisation process is brought about when globalization is combined with concentration in privileged places, thus establishing new relationships and interdependencies between a company and a particular region. Moreover, what is becoming more visible is the phenomena which are capable of bringing local, regional and global levels together, and this implies that businesses are becoming here the driving force. 
The goal of the paper was to analyse the new territorial approach to socio-economic development. The work uses largely a critical analysis of the literature on the subject.

\section{Territories in the economy}

The contemporary relevance given to a territory is increasingly more of an economic nature, as we are observing ever stronger interactions being established among economic entities located within a territory. The strength of those interactions is clearly driven by globalization, yet the ability to build them and to compete comes largely from the bottom-up initiatives incorporated in the objectives of local and regional development. In this way conditions are made for businesses operating globally, i.e. local entities, linking them with mutual connections or, among other things, the way they are organised, create a specific social structure known as a territory. In this understanding, a territory takes on a subjective character, it is not only a geographical space defined by administrative boundaries, but becomes a specific socio-economic actor.

One may venture to say that both local and regional levels are, to some extent, not only compelled to establish relations (predominantly spatial ones) with elements of the global economy, but they are also responsible for them. This makes territories evolve; their history is made up of subsequent development stages and new external situations which require their constant adaptation to socio-economic realities. Territory is a kind of new paradigm of development. Given those conditions, one could argue that integrating or contributing to the integration of economic actors is the very nature of a territory (Colletis-Wahl, 1995, pp. 805-806).

In comparing a territory with socio-economic space, one needs to emphasize that both production and non-production activities are located within this space, including all human settlements. Moreover, a territory affords businesses the opportunity for becoming embedded. The territorial dimension refers primarily to organizational conditions which allow for creative activities and facilitate their pursuit.

It is in this sense that the concept of territory becomes crucial for the current discussion centred around local and regional development. The concept can be defined in a variety of ways and from various perspectives, for Garofoli it is an area where market exchange and social forms of regulation meet, which determines various forms of production organisation and innovative abilities (Garofoli, 1993, p. 25). In this way, a territory is treated as a form of economic organisation, as a place of the collective, localised economic processes, defined by the proximity of the problems and the coordination of individual expectations and activities (Jewtuchowicz, 2016, p. 227). Similarly, Le Berre defines territory "as a part of the earth's surface adapted by a social group to ensure the reproduction of the provision of its vital needs" (Le Berre, 1992, p. 622). 
According to Jewtuchowicz, sociologists place a particular emphasis on human relationships, whereas economists stress transactions (Jewtuchowicz, 2005, p. 64). Moreover, he takes the view that "the most crucial characteristic of a territory is manifested in social relationships, relationships between a community of people and the area where they live, in belonging in this area which could be described by such concepts as: identity, appropriation of space, and getting embedded in a particular place. Territory is a system while development emerges largely as a social, and not merely technological process" (Jewtuchowicz, 2005, pp. 64-65).

According to Kopaliński, a territory is a piece of land located within specific lines; a geographical area under the authority of the state, a nonautonomous country (e.g. a colonial territory) with some degree of autonomy (Kopaliński, 1994, p. 509).

Moreover, the Dictionary of Polish Language defines territory as an area of land distinctive for its specific features (Skorupka, Auderska, \& Łempicka, 1969, p. 827).

For Szafranek, it is vital that a territory is seen as being closely linked to the category of territorial cohesion. The author argues that in the traditional approach, a territory is an area whose borders are clearly defined with the right of ownership or sovereignty. In this sense, a territory signifies towns, administrative regions or states (Szafranek, 2019, p. 54).

Jewtuchowicz draws attention to the fact that in recent years economic sciences have been developing the vision of territory which incorporates the concepts of organization, politics, economy and society, and where not only the historical, ideological and emotional dimension is present, but also the imaginative one (Jewtuchowicz, 2005, p. 65).

From the perspective of socio-economic geography and regional economy, a territory was usually associated with the very administrative units, and hence regions. They were viewed as areas where localities, businesses or local communities emerged and developed. The characteristics of a specific territory marked the quality of the elements making up its structure, however, over time spatial processes led to a shift in the way the territory was perceived and its borders defined. The criteria for determining the extent of territories varied, although they mostly included the size of area and population.

Across institutional economics and evolutionary economics, a territory has been interpreted as a space shaped historically, where a specific system based on institutions and relations emerged. This is a space with its own history and culture, accumulated knowledge and skills, enjoying an intensive network of relations between the actors (Pietrzyk, 2004, pp. 12-13). It can be perceived as (Domański \& Marciniak, 2003, pp. 131-132):

- a place where technology and innovation were born,

- a place for coordinating economic activities and a link between local external advantages and the organizational trajectories of firms,

- the seat of political bodies, which make decisions, create and allocate resources, as well as represent authority vis-à-vis businesses, 
- a place where non-commercial interdependencies emerge and develop. These interdependencies stimulate the technological and organizational progress of entities, and are conducive to coordinating those activities.

As such, the space is not limited to being a place for running businesses or being a production factor. In parallel with the socio-economic progress, it has become a relational space capable of processing signals (stimulus) or breaking them, spreading innovation or erecting barriers to them, and adapting to the dynamics of the processes it is involved in. The concept of relational space highlights the fact that creating added value and new resources is attributable to the relations between businesses, administration, scientific institutions and social organizations.

Pietrzyk believes that territory is defined through the prism of endogenous resources produced in an interactive and evolutionary way. It is a specific resource with its own culture and norms, logic of functioning and social architecture. Territory is not a space that can be defined by the size of accumulated resources or by its administrative borders; it is a space created by natural social and economic ties established by actors pursuing a common goal. The author suggests that "a territory is a space to live, a place of solidarity, cooperation and exchange, a place where identity is forged; it is a place created by a specific community" (Pietrzyk, 2004, pp. 12-13).

The concept of territory, which economic sciences have recently been developing, incorporates those of organization, politics, economy and society allowing for the inclusion of historical, ideological, emotional and even imaginative dimensions. Seen in this way, territory is a historical structure whose specific development has equipped it with its own technical and human potential. One can therefore say that a territory is a specific area within which commercial exchange takes place, thus exerting influence on various forms of production organization and capacity for innovation. As such, it is a place of collective situated economic processes.

What appears significant at this point is that a territory described in this way can have its own development dynamics. It can have weak internal relations (low qualifications of labour force, poor quality of economic environment), but there may also be territories capable of creating local production systems based on their own resources. This confirms that a territory is considered to represent some forms of social organization and interactions. Furthermore, it is a key element in linking the development both in the short and long term.

Nowadays, what mainly determines territorial units are issues relating to social identity and functional links. An indication of this can be found in the rules governing territorial division, the result of which should be the relatively permanent fragmentation of the state carried out by the rule of law, aimed at defining the underpinnings of activities conducted by state agencies and local government units.

Consequently, a territory is perceived as a specific social structure which draws on the history, culture, knowledge and skills shared by a particular community. 
These factors refer to both local and regional development, and represent a specific resource whilst being the product of this very development.

In light of the analysis above, one may suggest that the territorial approach emphasizes the unique features, dynamics and autonomy of development processes. Moreover, it moves away from the interpretation of space in terms of being a statistical place where resources and economic entities are located, in the direction of a dynamic approach defined through the prism of the local actors' relations and activities and social and institutional capital. In brief, in the theoretical approach a territory is perceived as follows (Nowakowska, 2017, p. 28):

- a historically formed place, with a strong social and institutional context, and with specific and unique resources,

- a place built by economic and social entities, dynamic interactions, an extensive relation network and activities drawing on partnership and cooperation,

- a place distinctive for its own way of coordinating behaviours, its internal system of rules and standards of cooperation and change management, behaviour and communication canon, as well as information and knowledge-sharing,

- a place where the competitive advantage capacity of economic entities is built, business transaction costs are reduced and the innovation capacity of companies is created.

The increased importance of territories and having them tied to the globalization of the economy and the transformation taking place in the production sphere made it necessary for the general concept of development to change. The ongoing discussion on this subject has brought to the fore the issue of spatial changes in production, leading to more general reflections on the role of territory in transforming the capitalist economy. In these discussions, territory is viewed as a "form of economic organization, a place of collective localized business processes" (Jewtuchowicz, Nowakowska, \& Przygodzki, 2006, p. 155). For these processes to be effective, one needs to make decisions concerned predominantly with such issues as where to locate businesses and to consider these decisions to be strategic ones for a company. Although companies must compete on a global scale with investments such as raw material, knowledge and capital flowing freely across the world, location still plays a key role in establishing competitive advantage. This makes the relations between the global and local levels more apparent. As suggested by Jewtuchowicz, "the effect brought about by the global and local platforms intersecting and interacting with each other was reflected in a newly coined term: glocalisation, which highlights the complementarity and simultaneity of increasing globalization and the growing importance of local development" (Jewtuchowicz, 2006, p. 164). 


\section{Glocalisation as a new paradigm of territorial development}

How the contemporary economic phenomena unfold is determined by the intertwining of interactions in their global and local cross-sections. The consequence is that spatial research can no longer be based on a national territory that is independent and marked by borders. Past arguments applying the categories of the national and the international are being supplanted by the exploration of global and local relations. Undoubtedly, this has led to the growing significance of the local development category, making it of interest to the globalization process. This category has been termed glocalisation.

Initially, this referred only to the economic dimension and meant adapting global marketing strategies to local conditions. The transfer of this concept to the realm of social sciences was made by Robertson, who defined glocalisation as the adaptation of global activities to local conditions, best expressed by the phrase "think globally, act locally". According to Robertson, the term was coined by Japanese economists to explain their own global marketing strategies. In this context, glocalisation is understood as producing products or offering services to global recipients while adjusting them to the requirements of local markets. The author identifies glocalisation with a kind of filter, thanks to which states will be able to save their cultural heritage from the "unifying influence of global capitalism" (Biernacka-Ligięza, n.d.). Soja extended Robertson's considerations by introducing the theory of the butterfly effect, according to which "analysing the problem of globalisation, we conclude that it is not a process taking place only on the scale of the entire planet, but it is considered from different perspectives and with different intensity on every scale of human life, from the human body to the planet" (Soja, 2000, p. 200). How all the scales of human life connect becomes an essential variable in understanding the glocal world.

Glocalisation could be viewed as a local dimension of globalization and which needs to be considered as specific (Luczyszyn, 2012a, p. 213). The decisions on where to locate business operations have always been one of the most critical strategic choices made by a company. It can hardly be denied that companies which hope to compete in today's economy have to make decisions as to where to locate every operation and how many locations there ought to exist (Jewtuchowicz, 2006, p. 165). At this point it is worth drawing attention to the glocalisation itself, given that it enables one to discern and analyse the following elements (Kuciński, 2011, p. 10):

- the reasons for and consequences of locating globally-oriented economic entities in a specific local environment (local socio-economic space),

- the conditions in which the local environment opens up and integrates with the rest of the world,

- the institutional place-specific solutions stimulating local development, conducive to attracting investment by globally-oriented economic entities. 
While addressing the issue of locating business operations and doing so in the context of globalization, one needs to discuss the concept of the sustainable development of a country and its individual regions. There is, however, one problem brought about by this situation, i.e. how to control the location of a business so that it can contribute to the development, while at the same time effectively reduce the adverse consequences arising from globalization, in particular the threats involved in it: "this is significant in that an optimal location, together with its regulations, represent an important tool (albeit not sufficiently appreciated and applied) for business and thereby the country's competitiveness" (Łuczyszyn, 2012a, p. 217). This is particularly relevant in that it enables one to assess the extent to which local companies use the assets and opportunities provided by the global location management and how regions, urban areas, counties and municipalities in general fail to adapt to these challenges. Table 1 presents some areas of global location management.

Table 1. Areas with global location management

\begin{tabular}{|c|c|}
\hline Areas & Description \\
\hline $\begin{array}{l}\text { Global } \\
\text { perspective } \\
\text { of business } \\
\text { location }\end{array}$ & $\begin{array}{l}\text { It shows that globalization analyses the perception of business location factors, their weight and } \\
\text { impact. This is mainly about cultural determinants and managers. Here the discussion is concerned } \\
\text { with some types of location behaviour on the part of foreign and domestic companies (how } \\
\text { foreign companies react to a new location). }\end{array}$ \\
\hline $\begin{array}{l}\text { Location } \\
\text { dilemmas } \\
\text { facing new } \\
\text { business } \\
\text { ventures }\end{array}$ & $\begin{array}{l}\text { This relates to locating new industrial, commercial, service and infrastructure investments, in } \\
\text { particular those involved in building energy security, which is acquiring a new dimension under } \\
\text { globalization. This issue has three aspects: } \\
\text { - how the existing economic structure and spatial organization of the country's national economy } \\
\text { impact on the way it is perceived by transnational corporations, especially by global businesses, } \\
\text { - how local businesses see the opportunities in terms of locating their new investment ventures } \\
\text { within the national and global economic space, } \\
\text { - the way in which state, regional and local public authorities react towards the location } \\
\text { behaviour of domestic and foreign economic entities. }\end{array}$ \\
\hline $\begin{array}{l}\text { Relocation } \\
\text { decisions } \\
\text { made by } \\
\text { domestic } \\
\text { companies }\end{array}$ & $\begin{array}{l}\text { These decisions demonstrate companies' strategies. The relocation of businesses is strongly } \\
\text { linked to the economic situation, being very sensitive to the negative impact arising from an } \\
\text { economic crisis. From the perspective of regional and local advantages, the question whether or } \\
\text { not a foreign company comes to a country, region or settlement unit choosing them for its location } \\
\text { as the result of globalization is less important than the question of whether it cooperates with local } \\
\text { businesses and institutions from the business environment, and if so, what is the nature of this } \\
\text { cooperation. } \\
\text { What is meant here is the process of becoming embedded in a new place, particularly in its } \\
\text { economic and spatial structure, as well as the social fabric. }\end{array}$ \\
\hline $\begin{array}{l}\text { Spatial context } \\
\text { of relations } \\
\text { between } \\
\text { locating } \\
\text { business } \\
\text { operations. }\end{array}$ & $\begin{array}{l}\text { While analysing a location, it is possible and advisable to look at this process not only from the } \\
\text { companies' point of view, but also from that of the spatial units where the businesses are located. } \\
\text { The reason for this is that the consequence of globalization is not only the opportunity for } \\
\text { businesses to look for locations across the globe, and even turning into the pressure for constantly } \\
\text { questioning whether the present location is the right one, but it is also about creating global, as } \\
\text { well as regional and local market of locations. }\end{array}$ \\
\hline
\end{tabular}

Source: (Kuciński, 2011, pp. 16-18). 
Based on the above, one might venture to suggest that glocalisation, seen as the other side of globalization, is becoming a prerequisite for today's local and regional development, and primarily for all new trends - the new paradigm of territorial development.

On the one hand, glocalisation indicates the role and place of the local development dynamics and the importance of local activities in the globalization process, while on the other hand, it shows the relevance and place of the global processes for the development strategies of a specific territory. According to Jewtuchowicz, "glocalisation allows one to gain an insight into how the global economy is becoming embedded in the historical territorial structures, and how it constantly uses the local resources, while simultaneously transforming them" (Jewtuchowicz, 2006, p. 165). This shows the dominance of the global context over the local one. In terms of business practice, it seems that glocalisation could be examined and evaluated from a variety of perspectives. However, two appear to be crucial; the first one is concerned with the reasons for and consequences arising from locating a (global) company in a particular area (territory), with the second one emphasising the conditions for opening up and interacting with the rest of the world by a territory, including the policy envisaged for raising its attractiveness. It seems that these approaches are linked to such traits as proximity and availability (two glocalisation characteristics). ${ }^{1}$ Accessibility has to do with 'displacement' and the possibility of establishing global socio-economic relations. In this sense, accessibility is related to the transfer of the global dimension into the local one. Accessibility is closely related to the concept of network and functional or organisational proximity, which has strong territorial conditions (Torres, 2004, p. 25).

\section{Territorialisation processes and territorial development}

One encounters the problem of territorialisation when globalization starts to be accompanied by the concentration in privileged places, establishing new relations and dependencies between a company and a specific region. A straightforward association can be made linking the company's success to that of the region and vice versa, or creating a situation where the success of the region will be a key factor for the company's competitiveness. These phenomena largely involve having the capacity for bringing together the local, regional and global levels, which would imply that in this regard transnational companies become the driving force. The way in which a company participates in the territorial development lays the groundwork for the development of this territory, while the process itself is referred to as the 'territorialisation of companies'. In business practice, the concept of territorialisation is manifested as a process which:

${ }^{1}$ They are the result of the progress made in information and communication technologies. 
- enables external businesses to integrate with local actors and be involved in organizing an environment for entrepreneurship and to create specific resources,

- contributes to internationalization of local businesses through the so-called 'moving' phenomenon. ${ }^{2}$

In the classical theories, the issues concerned with the relations between the company and territory were explored using the theories on location choices. However, under globalization such factors as distance and the market size have become less relevant. What has gained in significance is how the company becomes embedded in the structures of a particular territory and engaged in its development. The territories that have proven to be successful in this respect are often called "magnet places" as they show this peculiar capacity for attracting and keeping new kinds of competitive businesses. Such places are always considered to be more effective than others. What needs to be highlighted at this point is that a territory is necessary for businesses to develop technologies and implement production changes, while at the same time it develops its own logic of development, thus becoming part of the dynamics of change. These relations lead to the territory being less dependent on businesses because this process involves accumulating mainly technological resources, which, in turn, makes the territory more cohesive and less vulnerable to the crisis caused by relocating the company. One may see this as the relations and interdependencies between the territory and company. The company's independence lies in its ability to relocate and leave the place of its previous business operations, while the independence of the territory is manifested in its ability to withstand the losses caused by such a relocation. The independence of the territory will hinge on the density and strength of business and social relations between the local actors, with these relations determining the development dynamics.

In this view, territorialisation leads to establishing a specific creative system of relations which is capable of adapting quickly to changes and building added values. Dense and effective networks of relations create mechanisms which allow the actors to use and be involved in building territorial assets. This leads to ever bigger interdependencies between the actors within a territory, and to the greater diversity and specificity of this space. By allowing for the internationalization of external effects in the way that new competitive resources are being constantly created, it is this territorial dynamic that attracts outside investors and assets. The specific features of a particular territory are then considered to be the competitive advantage which can influence its development and even contribute to the change in its production method.

2 These are measures involving moving abroad a company, mostly from SME sector, thanks to the support offered by a large company as it allows the smaller one to use the international network of the former. 
Drawing on the above, one could argue that under such conditions the territorialisation process intensifies the economic ties as well as the changes in the spatial system. This, in turn, exerts a considerable influence on the relations between the space and the company, therefore an increase can be observed in the importance of the local scale and territorial factor.

Both regional and local development built on endogenous development factors see the community as the primary dimension. In this view, the development appears to be not only a commercial exchange but additionally the sum of social relations in a given socio-economic space with its own history and culture. The specific features characteristic of a particular territory become a significant element of competition. In practice this means competing by building on local and regional social and organizational innovations. Bearing in mind that these can take place across different spheres of the local and regional economy, they ought to be seen as both the capacity and will on the part of individual members of the society to break down the existing habits and customs, ways of perception and the types of goals underlying the allocative processes (Drucker, 2004, p. 17). Moreover, the interdependencies occurring between the dynamics of the industrial, service and territorial organizations become more apparent here. This suggests that the new ways of thinking, both theoretically and practically, strengthen the territory, allowing it to absorb technological and economic progress while simultaneously being its initiator. Thus, the social changes taking place across the territory induce, for instance, new relations between the territory and businesses. This reveals how the businesses influence the space structure and dynamics and why they choose a particular place for their operations. Hence, it may be worth stressing that "on the local scale, an important issue is the cooperation between various units and people, since creative and innovative solutions are brought about by multifaceted interactions. To this end, the best area appears to be a region (micro-region) given its geographic proximity, cultural ties, shared values, trust, all of which form the best foundation for developing a variety of flexible horizontal links" (Łuczyszyn, 2012b, p. 77). Proximity is a key determinant in terms of the dynamics and development level of a territory. This is borne out by the fact that some types of knowledge and information are shared more easily if done in a more useful manner. Proximity is not a strictly space-related concept, however it contributes to the emergence of a real social system. Proximity can be geographical, industrial, organizational or institutional. The territorial development is not only a result of commercial exchange; it is the result of a complex set of relations unfolding between actors gathered within a particular socio-economic space endowed with a culture and history. It is then that the specific features of a particular territory become its competitive advantage. 


\section{Conclusion}

In today's socio-economic realities the determinants of socio-economic development can be analysed and assessed from a variety of viewpoints. The most desirable would seems to be the one which refers predominantly to regional and local development, especially to the successes and failures of specific socio-economic spaces. Successful regional and local developments hinge primarily on local potentialities. This means that all new values (e.g. new jobs, environment quality, high level of safety, new infrastructure) must have a synergy effect, which proves that the shift in the regional development paradigm has taken place in the direction of making it territorial, hence the argument that there is a very clear need for creating, strengthening and using local and regional ties with a view to fostering the development policy and its territorial character.

In business practice, one of the elements which can allow one to conduct an analysis and assessment of a success or failure is glocalisation. It shows the reasons and consequences arising from locating a (global) company within a particular territory while highlighting the conditions for opening up and the interactions of the territory with the rest of the world, as well as the policy concerned with making the territory attractive. ${ }^{3}$ Naturally, the prerequisite for choosing a location for a business is the market, communication infrastructure and the right geographical location in terms of the company's operations. For micro-regions, for example, low property prices compared to metropolitan areas, human resources, the location of subcontractors and other companies within the same industry, can offer considerable opportunities. The initiatives of local governments are yet another important factor (tax exemptions and incentives, sureties, and improvements in the number and quality of infrastructure in terms of communication and information, as well as marketing and promotional tools). Moreover, glocalisation emphasizes the role and place of local development dynamics and the importance of local actions for the globalization process, while also highlighting the significance and place of global processes in the development strategies of a specific territory, proving that the global context dominates the local one.

The main themes of today's discussion in the context of territorialisation (territorially oriented development) relate primarily to experiences in the field of the development of globalisation processes so far, which lead to the conclusion that firstly, in the foreseeable future, attempts to centrally regulate them in the form of some form of 'world government' and its agendas are unrealistic. However, this does not exclude various forms of coordination of these processes at their lower levels - interregional, regional, and local. Secondly, the conviction that the neoliberal development model needs to be changed is becoming more and more common. Thirdly, the importance

${ }^{3}$ The issue of the location for economic entities in socio-economic spaces is worth stressing, as the location factors need to be defined as to whether they are universal or specific (e.g. they are considered to be peripheral). 
of the global determinant of diversity and local development processes is growing, which require new, adapted forms of coordination and cooperation in conditions of incomplete globalisation (Herman, 2015, p. 5). Therefore, among others, in the conditions of the European Union, the most important aspect is territorial cohesion, which means ensuring the harmonious development of all these places and guarantees that their inhabitants will be able to make the best use of the specific features of these areas. Such coherence serves to transform diversity into benefits, contributing to the sustainable development of the Union as a whole. Territorial cohesion highlights the need for an integrated approach to problem-solving at the appropriate territorial level, which may require the cooperation of local, regional, and even national authorities.

\section{References}

Biernacka-Ligięza, I. (n.d.). Glokalizacja - byt wyobrażony czy realna potrzeba? Retrieved August 31, 2021 from https://repo.uni.opole.pl/

Colletis-Wahl, K. (1995). L'hypothèse des facteurs de concurrence spatiale, quels fondements? Revue d'Economie Régionale et Urbaine, (5).

Domański R., \& Marciniak A. (2003). Sieciowe koncepcje gospodarki miast i regionów. Studia. Polska Akademia Nauk. Komitet Przestrzennego Zagospodarowania Kraju, 113.

Drucker, P. F. (2004). Natchnienie i fart, czyli innowacja i przedsiębiorczość. Warszawa: Wydawnictwo Studio Emka.

Garofoli, G. (1993). Economic development, organisation of production and territory. Revue d'Economie Industrielle, (64).

Herman, A. (2015). Globalizacja poprzez glokalizację. Kwartalnik Nauk o Przedsiębiorstwie, 36(3).

Jewtuchowicz, A. (2005). Terytorium i współczesne dylematy jego rozwoju. Łodź: Wydawnictwo Uniwersytetu Łódzkiego.

Jewtuchowicz, A. (2006). Terytorium, terytorializacja, rozwój regionalny. In A. Klasik (Ed.), Przedsiębiorczość i konkurencyjność a rozwój regionalny. Katowice: Wydawnictwo Akademii Ekonomicznej w Katowicach.

Jewtuchowicz, A. (2016). Terytorium i terytorializacja w europejskiej polityce rozwoju regionalnego. Studia Prawno-Ekonomiczne, XCVII.

Jewtuchowicz, A., Nowakowska, A., \& Przygodzki, Z. (2006). Strategie dużych firm a proces terytorializacji - wprowadzenie metodologiczne. In A. Klasik (Ed.), Przedsiębiorczość i konkurencyjność a rozwój regionalny. Katowice: Wydawnictwo Akademii Ekonomicznej w Katowicach.

Kopaliński, W. (1994). Słownik wyrazów obcych i zwrotów obcojęzycznych. Warszawa: Wydawnictwo Wiedza Powszechna.

Kuciński, K. (2011). Glokalizacja. Warszawa: Difin.

Le Berre, M. (1992). Territoire. In A. Baill, R. Ferras, \& D. Pumain, Encyclopédie de géographie. Paris: Economica.

Łuczyszyn, A. (2012a). Glokalizacja we współczesnej gospodarce a wybrane problemy rozwoju lokalnego. In P. Grabowiec (Ed.), Przegląd historyczno-politologiczny, Rok V, 1(9). Wrocław: Wydawnictwo Wyższej Szkoły Zarządzania i Finansów we Wrocławiu.

Łuczyszyn, A. (2012b). Innowacje społeczne jako determinanta rozwoju lokalnego. Biblioteka Regionalisty, (12).

Nowakowska, A. (2017). Terytorializacja rozwoju i polityki regionalnej. Biuletyn KPZK PAN, (268). 
Pietrzyk, I. (2004). Globalizacja, integracja europejska a rozwój regionalny. In A. Jewtuchowicz (Ed.), Wiedza, innowacyjność, przedsiębiorczość a rozwój regionalny. Łódź: Wydawnictwo Uniwersytetu Łódzkiego.

Skorupka, S., Auderska, H., \& Łempicka, Z. (1969). Mały słownik języka polskiego. Warszawa: PWN. Soja, E. W. (2000). Postmetropolis: Critical studies of cities and regions. Oxford: Blackwell Publishers Ltd.

Szafranek, E. (2019). Terytorializacja polityki rozwoju. Opole: Uniwersytet Opolski.

Torres, O. (2004). Lokalna globalizacja czy globalna lokalizacja. Rozważania na temat glokalizacji. In A. Jewtuchowicz (Ed.), Wiedza, innowacyjność, przedsiębiorczość a rozwój regionów. Łodź: Wydawnictwo Uniwersytetu Łódzkiego. 